Jurnal Keuangan dan Perbankan, Vol.20, No.1 Januari 2016, hlm. 32-41

Terakreditasi SK. No. 040/P/2014

http://jurkubank.wordpress.com

\title{
DAM PAK CORPORATE GOVERNANCE TERHADAP KEPUTUSAN DIVIDEN (Literature Review Pada Negara-negara di Asia, Australia dan Afrika)
}

\author{
Nur Hidayati \\ Hadi Sunaryo \\ Fakultas Ekonomi Jurusan M anajemen Universitas Islam M alang
}

\begin{abstract}
This study aimed to analyzethe impact of corporategovernance towards dividend policy in several countries in A sia, A ustralia, and A frica. Focusing on literature review and analyzing the result with theoretical and practical implication disscussed in this paper. Based on paper review, we generalize corporate governance have significant and negative effect towards dividend policy. But werealize that result from such countries studied show neither confirmation or rejection to subtitutivetheory. Thereareal so conceptual model proposed from literaturereview from previous empirical result about effect of corporate governance toward dividend policy.Suggest for future research discussed to gain valuable information about corporate governance and dividend policy.
\end{abstract}

Keyw ords: corporategovernance, dividend policy

Suad Husnan dan Enny Pudjiastuti menyatakan bahwa: "Kebijakan dividen adalah kebijakan yang menyangkut tentang masalah penggunaan laba yang menjadi hak para pemegang saham, pada dasarnya laba tersebut bisa dibagi sebagai dividen atau ditahan untuk diinvestasikan kembali". A pabila perusahaan memilih untuk membagikan laba sebagai dividen, maka akan mengurangi laba yang ditahan dan selanjutnya mengurangi total sumber dana internal (internal financing). Sebaliknya jika perusahaan memilih untuk menahan laba yang diperoleh, maka kemampuan pembentukan dana internal akan semakin besar.

Kebijakan Dividen Optimal adalah kebijakan dividen yang mencapai suatu keseimbangan antara dividen saat ini dan pertumbuhan di masa yang akan datang untuk memaksimalkan harga saham perusahaan.Aspek negatif dari dividen adalah bahwa dividen tidak diinginkan oleh debt holders, karena hal ini berpotensi menguras dasar jaminan yang tersedia untuk debt holders dan berpotensi meningkatkan biaya utang. Utang diyakini memain-

Korespondensi dengan Penulis:

Nur Hidayati: Telp. -

Email: - 


\section{Dampak Corporate Governance terhadap Keputusan Dividen}

Nur Hidayati \& Hadi Sunaryo

kan peran penting dalam monitoring manajer. Secara khusus, leverage keuangan telah dikemukakan oleh Jensen dan M eckling (1976) dan Jensen (1986), antara lain, untuk memainkan peran dalam mengurangi biaya agensi yang timbul dari konflik pemegang saham-manager. Farinha (2003) berpendapat bahwa utang mungkin menyebabkan pembayaran dividen berkurang karena perjanjian utang dan terkait pembatasan yang dapat dikenakan oleh pemegang utang. Oleh karena itu, perusahaan de ngan leverage keuangan tinggi dan resiko keuangan tersirat mungkin dibatasi dari membayar dividen lebih.

A gency problem dapat dibatasi melalui mekanisme tata kelola perusahaan internal (peran dewan direksi dan kontrak kompensasi eksekutif) dan eksternal (pasar untuk kontrol perusahaan dan direct action/ aktivitas pemegang saham) (John dan Senbet, 1998). Karakteristik dewan yang penting meliputi ukuran dewan, komposisi dewan, dan peran CEO. Dewan yang besar memiliki kecenderungan memperlakukan tata kelola dan operasi perusahaan untuk pengawasan dan pemantauan yang lebih besar (John dan Senbet, 1998). Sehubungan dengan komposisi dewan, Yermack (1996) berpendapat bahwa memiliki proporsi yang tinggi dari direktur non-eksekutif cenderung meningkatkan independensi dewan perusahaan. Tingginya proporsi direksi luar menyediakan forum yang lebih baik untuk membuat keputusan korporasi berkualitas (Fama dan Jensen, 1983; Jensen, 1993; Kyereboah-Coleman dan Amidu, 2008).

Fama dan Jensen (1983) menyatakan bahwa konsentrasi pengambilan keputusan dan kontrol keputusan dalam satu individu mengurangi efektivitas dewan dalam memantau manajemen. Dalam hal sistem pemerintahan eksternal, bl ockholders institusional juga dapat bertindak sebagai perangkat monitoring manajer perusahaan. $\mathrm{H}$ al ini karenamasalah agensi dikatakan minim dalam perusahaan dengan pemegang saham blok besar yang mampu memonitor kegiatan pengelolaan (Shleifer dan Vishny, 1986), sehingga mengurangi kebutuhan untuk pembayaran dividen yang tinggi. Pemantauan blockholders diharapkan akan lebih intens dalam kehadiran blockholders institusional dengan kepemilikan besar di perusahaan. Terdapat kemungkinan bagi pemegang saham institusional untuk mempengaruhi pembayaran dividen yang lebih tinggi oleh perusahaan untuk meningkatkan pengawasan manajerial dengan pasar modal eksternal, yaitu jika mereka percaya upaya pemantauan langsung dari mereka sendiri tidak cukup atau terlalu mahal.

Di sisi lain, Jensen dan Meckling (1976) berpendapat bahwa ketika pemegang saham terlalu tersebar untuk mengambil tindakan terhadap maksimalisasi perilaku non-nilai, orang dalam dapat menggunakan aset perusahaan untuk keuntungan pribadi mereka sendiri, seperti melalaikan tanggungjawab dan mengkonsumsi keuntungan/ penghasilan tambahan.

Isu corporategovernancemuncul karena terjadi pemisahan antara kepemilikan dengan pengendalian perusahaan. Corporategovernancemenjadi pentinguntuk di implementasikan khususnya pada perusahaan go public karena berdampak pada keunggulan kompetitif perusahaan di mata masyarakat. Good corporate governance secara definitif merupakan sistem yang mengatur dan mengendalikan perusahaan untuk menciptakan nilai tambah (value added) untuk semua stakeholder.

A da dua hal yang ditekankan dalam konsep ini, pertama, pentingnya hak pemegang saham untuk memperoleh informasi dengan benar (akurat) dan tepat pada waktunya dan, kedua, kewajiban perusahaan untuk melakukan pengungkapan (disclosure) secara akurat, tepat waktu, dan transparan terhadap semua informasi kinerja perusahaan, kepemilikan, dan stakeholder (YPPMI \& SC, 2002).

Menurut Ho dan Wong (2001), corporate governance dipandang sebagai cara yang efektif untuk menggambarkan hak dan tanggung jawab masingmasing kelompok stakeholder dalam sebuah perusahaan dimana transparasi merupakan indikator utama standar corporate governance dalam sebuah 


\section{Jurnal Keuangan dan Perbankan | KEUANGAN}

Vol. 20, N o.1, Januari 2016: 32-41

ekonomi. Corporategovernance diperkenalkan untuk mengontrol masalah agen dan memastikan bahwa manajemen bertindak sesuai dengan harapan para pemegang saham, selain itu pengaruh dari corporate governance terhadap pengungkapan informasi sosial perusahaan dapat bersifat sebagai tambahan atau pengganti (Ho dan Wong, 2001).

Studi empiris pada tata kelola perusahaan dan kebijakan dividen perusahaan telah menunjukkan hasil yang menarik. Dalam sebuah studi oleh Fenn dan Liang (2001), yang menyelidiki bagaimana insentif saham manajerial mempengaruhi kebijakan pembayaran dividen, mereka menemukan bahwa insentif saham manajerial mengurangi biaya agensi untuk perusahaan dengan masalah kelebihan arus kas. Hasil penelitian mereka menunjukkan adanya hubungan negatif antara manajemen berbasis saham dan kebijakan pembayaran dividen perusahaan.

Jiraporn dan Ning (2006) meneliti dampak tata kelola perusahaan terhadap kebijakan dividen, dengan hak pemegang saham sebagai proxy untuk tata kelola perusahaan. Dengan sampel yang digunakan adalah 1.500 perusahaan AS dari NYSE, AMEX dan NASDAQ, hasil mengungkapkan adanya korelasi negatif antara hak pemegang saham dan kebijakan dividen, karena itu mereka mengkonfirmasi teori substitusi. Knyazeva (2007) mengkaji dampak tata kelola perusahaan pada perilaku pembayaran dividen perusahaan. Hasil penelitian menunjukkan bahwa investor akan mendorong lebih keras pada perusahaan dengan tata kelola perusahaan yang buruk untuk membayar dividen. Perusahaan dengan indeks nilai tata kelola perusahaan yang lebih rendah memberikan pembayaran dividen yang lebih tinggi kepada investor. Hasil ini menegaskan hubungan negatif antara tata kelola perusahaan dan kebijakan dividen, sehingga Knyazeva (2007) menegaskan tentang teori substitusi.

Sementara Mitton (2004) menggunakan sampel 365 perusahaan dari 19 negara dan menemukan bahwa, perusahaan dengan tata kelola per- usahaan yang lebih kuat memiliki pembayaran dividen yang lebih tinggi, konsisten dengan model agency - dividen. Terdapat pola hubungan signifikan negatif antara pembayaran dividen dan peluang pertumbuhan antara perusahaan dengan tata kelola yang lebih baik. Selain itu, perusahaan dengan pemerintahan yang lebih kuat juga lebih menguntungkan, tetapi profitabilitas yang lebih besar menjelaskan hanya bagian dari pembayaran dividen yang lebih tinggi. H asilnya juga menunjukkan hubungan yang positif antara tata kelola perusahaan dan dividen pembayaran di negaranegara dengan perlindungan investor yang kuat, sehingga tata kelola perusahaan dan tingkat perlindungan investor di suatu negara berperan untuk melengkapi dan bukan sebagai pengganti.

Kowalewski et al. (2008) menyelidiki hubungan antara praktik tata kelola perusahaan dan kebijakan dividen di Polandia. Mereka menggunakan daftar perusahaan di Warsaw Stock Exchangeselama periode 1998-2004 serta menggunakan indeks transparansi dan pengungkapan (TDI) sebagai proksi corporategovernance, hasil mereka menunjukkan bahwa peningkatan tata kelola perusahaan dikaitkan dengan peningkatan pembayaran dividen oleh perusahaan. Jadi, praktek tata kelola perusahaan yang lebih baik akan memberikan perlindungan lebih besar pada investor.

A djaoud dan Ben-Amar (2010) meneliti hubungan antara kualitas tata kel ola perusahaan dan kebijakan dividen di Kanada. Penggunaan sampel 714 perusahaan yang terdaftar di Bursa Efek Toronto selama periode 2002-2005, mereka menemukan bahwa perusahaan dengan tata kelola perusahaan yang lebih kuat memiliki pembayaran dividen yang lebih tinggi. Hasil penelitian menunjukkan bahwa kebijakan komposisi dewan dan hak pemegang saham yang berhubungan positif dengan rasio payout.

Penerapan good corporategovernance(GCG) dalam perusahaan merupakan suatu sistem yang dapat melindungi pemegang saham dari penyalahgunaan wewenang manajemen. Hasil penelitian 


\section{Dampak Corporate Governance terhadap Keputusan Dividen}

Nur Hidayati \& Hadi Sunaryo

terdahulu telah menunjukkan GCG berimplikasi pada keputusan pembagian dividen kepada pemegang saham. Studi Mitton (2004), La Porta, et al (2000) dan Kowalewski, etal (2007) menunjukkan GCG mempunyai pengaruh yang positif pada kebijakan dividen. Gambaran tersebut menunjukkan bahwa perusahaan-perusahaan dengan corporate governanceyang lebih ketat akan cenderung membagikan dividen yang lebih tinggi kepada pemegang saham.

Gugler (2003), John dan Knyazeva (2006) dan Kanagaretnam, et al (2007) dalam studinya menunjukkan hasil bahwa GCG berpengaruh negatif terhadap kebijakan dividen. Gambaran ini mengindikasikan bahwa perusahaan yang tidak menerapkan GCG akan membagikan dividen kepada pemegang saham dengan tujuan pemegang saham tetap berinvestasi dalam perusahaan.

Dari beberapa uraian singkat tentang hasil studi empiris, diketahui bahwa corporate governance menunjukkan adanya hubungan atau pengaruh negatif terhadap kebijakan dividen (Fenn dan Liang, 2001; Gugler, 2003; John dan Knyazeva, 2006; Jiraporn dan Ning, 2006; Kanagaretnam, et al., 2007; Knyazeva, 2007) dan hubungan atau pengaruh positif terhadap kebijakan dividen (Mitton, 2004; Kowalewski et al.,2008; Adjaoud dan Ben-A mar, 2010).

Permasalahan yang diangkat dalam penelitian ini pada dasarnya dikaitkan dengan dampak corporate governance terhadap kebijakan dividen dari perusahaan-perusahaan di beberapa negara di Asia, Australia, dan Afrika. Banyak penelitianpenelitian sebelumnya yang menemukan adanya pengaruh antara corporate governance terhadap kebijakan dividen (Fenn dan Liang, 2001; J iraporn dan Ning, 2006; Knyazeva, 2007; Mitton, 2004; Kowalewski et al.,2008; Adjaoud dan Ben-Amar, 2010), namun dalam penelitian ini akan dilihat bagaimana pengaruh tersebut dilihat dari perspektif negara berkembang dan negara maju di Asia, Australia, dan Afrika, mengingat struktur tata kelola perusahaan, struktur kepemilikan dan kerangka kelembagaan di sebagian besar negara dan benua memiliki fungsi yang berbeda.

Pada dasarnya penelitian ini bertujuan untuk mengkaji lebih dalam melalui meta analisis dari beberapa penelitian terdahulu khususnya dalam perspektif tata kelola governance dan kebijakan dividen. Hasil penelitian yang menunjukkan dampak positif maupun negatif menjadi pertimbangan utama untuk mengangkat tema tentang tata kelola terhadap kebijakan deviden. Pendalaman terhadap hasil penelitian tersebut diharapkan membawa perspektif baru dalam pola hubungan tata kelola dengan kebijakan deviden.

\section{METODE}

Dengan menggunakan kajian literatur, penelitian ini berusaha mengungkap fenomena lebih mendalam tentang tata kelola terhadap kebijakan deviden. Beberapa penelitian terdahulu tata kelola atas kebijakan deviden dalam konteks asia, afrika, dan australia menjadi subyek pembahasan penelitian. Unit analisis dalam penelitian ini adalah pola hubungan tata kelola terhadap kebijakan deviden perusahaan. Dengan mengambil lima penelitian terkait, literature review analysis dilakukan untuk menghasilkan output berupa meta analisis disajikan dalam penelitian untuk mengungkap fenomena penelitian dengan lebih mendalam, sehingga dapat memberikan kesimpulan tentang permasalahan tata kelola dan kebijakan deviden terutama di lingkup A sia,Afrika, dan Australia.

Penelitian-penelitian sebelumnya yang menemukan adanya pengaruh antara corporate governance terhadap kebijakan dividen (Fenn dan Liang, 2001; Jiraporn dan Ning, 2006; Knyazeva, 2007; Mitton, 2004; Kowalewski et al.,2008; Adjaoud dan Ben-Amar, 2010), namun dalam penelitian ini akan dilihat bagaimana pengaruh tersebut dilihat dari perspektif negara berkembang dan negara maju di Asia, Australia, dan Afrika, mengingat struktur tata kelola perusahaan, struktur kepemilikan dan kerangka kelembagaan di sebagi- 


\section{Jurnal Keuangan dan Perbankan | KEUANGAN}

Vol. 20, N o.1, Januari 2016: 32-41

an besar negara dan benua memiliki fungsi yang berbeda.

Terdapat lima penelitian tentang tata kelola atas kebijakan deviden dalam N egara A sia, A frika,
A ustralia yang ditelaah secara mendalam pada penelitian ini. Secara singkat tabel meta analisis penelitian tersebut antara lain sebagai berikut:

Tabel 1. Meta Analisis untuk Penelitian Terdahulu

\begin{tabular}{|c|c|c|c|c|c|}
\hline $\begin{array}{l}\text { Penulis } \\
\text { (Tahun) }\end{array}$ & $\begin{array}{l}\text { Jumlah } \\
\text { Sampel }\end{array}$ & $\begin{array}{c}\text { Karakteristik } \\
\text { Sampel }\end{array}$ & $\begin{array}{c}\text { Konsep } \\
\text { Tata } \\
\text { Kelola }\end{array}$ & $\begin{array}{c}\text { Konsep } \\
\text { Kebijakan } \\
\text { Dividen }\end{array}$ & $\begin{array}{l}\text { Temuan } \\
\text { Penting }\end{array}$ \\
\hline $\begin{array}{l}\text { Setiawan } \\
\text { dan Phua } \\
(2013)\end{array}$ & 248 & $\begin{array}{l}\text { Terdaftar di } \\
\text { bursa efek yang } \\
\text { mengumuman } \\
\text { kebijakan } \\
\text { deviden } \\
\text { diantara tahun } \\
2004 \text { - } 2006\end{array}$ & $\begin{array}{l}\text { Indeks transparansi } \\
\text { dan pengungkapan } \\
\text { (TDI - Transparancy } \\
\text { D isclosure Index) }\end{array}$ & $\begin{array}{l}\text { Pengumuman } \\
\text { pembayaran } \\
\text { dividen selama } \\
\text { periode } \\
\text { pengamatan. }\end{array}$ & $\begin{array}{l}\text { Penegasan penerapan teori subtitusi } \\
\text { dibandingkan teori hasil, yakni perusahaan } \\
\text { Indonesia cenderung mengkompensasi tata } \\
\text { kelola perusahaan mereka yang buruk } \\
\text { melalui pembayaran dividen yang lebih } \\
\text { tinggi. }\end{array}$ \\
\hline $\begin{array}{l}\text { Harada } \\
\text { dan } \\
\text { Nguyen } \\
\text { (2011) }\end{array}$ & 1.431 & $\begin{array}{l}\text { Perusahaan non } \\
\text { keuangan, } \\
\text { terdaftar di } \\
\text { NIKKEI NEEDS } \\
\text { dan Bureau Van } \\
\text { Dijk's OSIRIS } \\
\text { database }\end{array}$ & $\begin{array}{l}\text { Konsentrasi } \\
\text { kepemilikan } \\
\text { sebagai salah satu } \\
\text { proksi tata kelola } \\
\text { yang diangkat } \\
\text { dalam penelitian }\end{array}$ & $\begin{array}{l}\text { (1) Rasio } \\
\text { dividen } \\
\text { dengan } \\
\text { pendapatan } \\
\text { operasional } \\
\text { (DIVTOI) } \\
\text { (2) Rasio } \\
\text { dividen } \\
\text { dengan nilai } \\
\text { buku ekuitas } \\
\text { (DIVEQT) } \\
\end{array}$ & $\begin{array}{l}\text { Konsentrasi kepemilikan dikaitkan dengan } \\
\text { dividen secara signifikan lebih rendah } \\
\text { dalam proporsi pendapatan serta relatif } \\
\text { terhadap ekuitas buku. Relasi endogen } \\
\text { antara konsentrasi kepemilikan dan } \\
\text { dividen payout, tapi hasilnya tidak berbeda } \\
\text { secara statistik. Perusahaan dengan } \\
\text { kepemilikan yang terkonsentrasi juga } \\
\text { kurang mungkin meningkatkan dividen } \\
\text { bila penghasilan meningkat atau ketika } \\
\text { penurunan utang }\end{array}$ \\
\hline $\begin{array}{l}\text { Zhang } \\
\text { (2005) }\end{array}$ & 246 & $\begin{array}{l}\text { 123 industri } \\
\text { terdaftar di } \\
\text { bursa Shanghai } \\
\text { dan Shenzen, } \\
\text { serta } 123 \\
\text { industri yang } \\
\text { terdaftar di } \\
\text { bursa } \\
\text { Hongkong }\end{array}$ & $\begin{array}{l}\text { Friksi manajer } \\
\text { dalam dewan } \\
\text { direksi, struktur } \\
\text { dewan, CEO dan } \\
\text { dewan direksi yang } \\
\text { diadopsi sebagai } \\
\text { pengukuran tata } \\
\text { kelola perusahaan } \\
\text { (Standard and } \\
\text { Poor's } 17 \text { and CLSA } \\
\text { 18, 2002) }\end{array}$ & $\begin{array}{l}\text { D iv / Earn } \\
\text { adalah rasio } \\
\text { dividen / laba, } \\
\text { dividen bersih o } \\
\text { dividen tunai } \\
\text { pajak f dibayar } \\
\text { selama tahun } \\
\text { fiskal; laba } \\
\text { adalah dari } \\
\text { setelah pajak } \\
\text { dan } \\
\text { kepentingan, } \\
\text { yaitu, laba } \\
\text { bersih. }\end{array}$ & $\begin{array}{l}\text { Perbedaan praktek tata kelola dan } \\
\text { dampaknya untuk perusahaan di cina } \\
\text { daratan dan cina hongkong. Di cina } \\
\text { daratan, pengaruh manajer dalam direksi, } \\
\text { serta memiliki keahlian manajerial yang } \\
\text { lebih tinggi di direksi cenderung untuk } \\
\text { membayar dividen tunai yang lebih rendah } \\
\text { dan menciptakan permasalahan agensi } \\
\text { yang serius. Sementara di hongkong } \\
\text { perusahaan lewat manajernya selalu } \\
\text { terdorong oleh harga pasar dalam } \\
\text { membayar deviden. }\end{array}$ \\
\hline $\begin{array}{l}\text { Abor } \\
\text { Fiador } \\
\text { (2013) }\end{array}$ & 525 & $\begin{array}{l}\text { Perusahaan } \\
\text { Ghana, Nigeria, } \\
\text { Kenya, dan } \\
\text { Afrika Selatan } \\
\text { Terdaftar di } \\
\text { bursa efek yang } \\
\text { mengumuman } \\
\text { kebijakan } \\
\text { deviden } \\
\text { diantara tahun } \\
\text { 1997 - } 2006\end{array}$ & $\begin{array}{l}\text { Empat ukuran tata } \\
\text { kelola, yakni } \\
\text { (1) Komposisi } \\
\text { dewan } \\
\text { (2) Ukuran dewan } \\
\text { (3) Dualitas CEO } \\
\text { (4) Kepemilikan } \\
\text { institusional }\end{array}$ & $\begin{array}{l}\text { Dividend } \\
\text { payout dan } \\
\text { didefinisikan } \\
\text { sebagai rasio } \\
\text { dividen } \\
\text { terhadap laba. } \\
\text { Dividen total } \\
\text { dividen tunai } \\
\text { yang } \\
\text { dibayarkan } \\
\text { kepada } \\
\text { pemegang } \\
\text { saham. }\end{array}$ & $\begin{array}{l}\text { Struktur tata kelola perusahaan yang baik } \\
\text { mendorong tingginya dividend payout, hal } \\
\text { ini dikarenakan kemudahan akses finansial } \\
\text { dan biaya keuangan eksternal rendah. Hal } \\
\text { ini menunjukkan pentingnya faktor } \\
\text { eksternal dalam memoderasi pola } \\
\text { hubungan tersebut. }\end{array}$ \\
\hline $\begin{array}{l}\text { Yarram } \\
\text { (2015) }\end{array}$ & 413 & $\begin{array}{l}\text { Perusahaan non } \\
\text { keuangan di } \\
\text { Australia } \\
\text { periode waktu } \\
2004 \text { - } 2009\end{array}$ & $\begin{array}{l}\text { Penggunaan indeks } \\
\text { tata kelola yang } \\
\text { menggunakan } \\
\text { pelaporan pihak } \\
\text { ketiga } \\
\text { (WHK Horwath / } \\
\text { University of } \\
\text { Newcastle CG } \\
\text { Laporan untuk } \\
\text { tahun 2004-2009) }\end{array}$ & $\begin{array}{l}\text { Pengumuman } \\
\text { pembayaran } \\
\text { dividen selama } \\
\text { periode } \\
\text { pengamatan, } \\
\text { Worldscope } \\
\text { (Datastream) } \\
\text { Database. }\end{array}$ & $\begin{array}{l}\text { Perusahaan yang diatur dengan baik } \\
\text { dapat membatasi kesempatan bagi manajer } \\
\text { untuk mengambil alih peran pemegang } \\
\text { saham dan dengan demikian perusahaan } \\
\text { dapat mengurangi biaya kontrak yang } \\
\text { terkait dengan kebijakan kompensasi. }\end{array}$ \\
\hline
\end{tabular}




\section{Dampak Corporate Governance terhadap Keputusan Dividen}

N ur H idayati \& Hadi Sunaryo

Dari hasil literature review pada Tabel 1 diketahui bahwa Setiawan dan Lian (2013) menemukan adanya pengaruh signifikan dan positif antara corporate governance terhadap kebijakan dividen. Harada dan Pascal (2011) menemukan adanya pengaruh positif antara corporate governance terhadap kebijakan dividen apabila pemegang saham besar menggunakan dividen untuk membatasi oportunisme manajerial, tetapi negatif jika mereka memilih untuk mengejar kepentingan mereka sendiri dengan mengorbankan para pemegang saham kecil. Zhang (2005) menemukan adanya pengaruh yang signifikan negatif antara corporate governance dengan kebijakan dividend pada perusahaan yang terdaftar di Cina daratan, sedangkan menunjukkan pengaruh yang signifikan positif pada perusahaan yang terdaftar di Hong Kong. Yarram (2015) menemukan adanya pengaruh positif yang signifikan dari tata kelola perusahaan pada keputusan untuk membayar dividen serta pembayaran dividen rata-rata. A bor dan Viador (2013) menemukan bahwa corporate governance mempunyai pengaruh signifikan dan positif terhadap pembayaran dividen pada perusahaan A frika Selatan, Kenya, dan Ghana, sedangkan mempunyai pengaruh signifikan dan negatif pada perusahaan Nigeria.

Secara umum baik tata kelola maupun kebijakan dividen dikonseptualisasikan dan diukur dengan cara yang berbeda. Tata kelola perusahaan dapat diukur berdasarkan indeks dari lembaga berwenang yang mempublikasikan, dan atau melihat struktur kepemilikan serta pola hubungan diantara manajemen dan direksi. Sementara kebijakan dividen diukur dengan rasio maupun tentang pengumuman pembayaran dalam periode pengamatan.

Beberapa penelitian menunjukkan kontradiksi hasil diantara pola hubungan tata kelola dengan kebijakan dividen (Harada dan Pascal, 2011; Zhang, 2005; Abor dan Viador, 2013). Hal ini dikarenakan moderasi dari hal - hal eksternal dari hubungan tata kelola dan kebijkan dividen perusahaan.

\section{HASIL DAN PEM BAHASAN}

Dari kelima rujukan utama yang digunakan untuk membahas pola hubungan diantara tata kelola dengan kebijakan deviden, maka dapatdigeneralisir beberapa hal sebagai berikut:

Dalam pola hubungan tata kelola dengan kebijakan deviden, sangat perlu memperhatikan teori subtitusi, dimana hal ini sangat menonjol terlihat dalam beberapa praktik tata kelola perusahaan di Asia, Australia, dan Afrika. Bahwasanya perusahaan mengejar profit atau maksimalisasi nilai pemegang saham, keduanya secara tegas harus dipilih salah satunya, tidak untuk dijalankan keduanya.

Baik maksimalisasi nilai shareholder atau profit, kajian dari beberapa penelitian tersebut menyiratkan peran penting dari manajer dalam mengakomodir kedua kondisi tersebut di dalam menjalankan roda organisasi serta menetapkan orientasi investasi yang diterapkan perusahaan.

Belum terdapat ukuran yang baku mengenai konsep tata kelola perusahaan, yang lebih cenderung diproksikan dalam struktur kepemilikan serta hubungan manajemen dengan direksi. Sementara konsep dividen dapat diukur melalui perhitungan rasio ataupun pengumuman pembayaran.

Meskipun tatakelola perusahaan (yang lebih sering diproksikan dalam bentuk struktur kepemilikan dalam perusahaan) berdampak penting bagi kebijakan deviden (baik positif maupun negatif), sesungguhnya bagi perusahaan tidak terlepas dari faktor - faktor eksternal dalam menentukan kebijakan deviden bagi pemegang saham. Seringkali pola hubungan tata kelola dengan kebijakan deviden perusahaan dapat dimoderasi oleh faktor faktor lain yang dapat teridentifikasi secara teoritis maupun empiris. 


\section{Jurnal Keuangan dan Perbankan | KEUANGAN}

Vol. 20, N o.1, Januari 2016: 32-41

Dengan demikian, dari poin terakhir tersebut diatas dampak corporate governance terhadap kebijakan dividen pada negara berkembang dan negara maju pada dasarnya dapat bergantung pada beberapa hal Iain di sekitar perusahaan, antara lain:

Kondisi Perekonomian, Kondisi perekonomian suatu negara sangat mempengaruhi arus investasi di negara tersebut, karena berhubungan dengan persepsi dan kepercayaan dari investor. Sehingga dengan pemerintahan yang baik, diharapkan dapat memotivasi para pengambil keputusan untuk mengikuti kebijakan dividen yang optimal yang memaksimumkan kekayaan pemegang saham. Semakin tinggi dividen yang ditawarkan pada investor, maka akan semakin mendorong mereka untuk berinvestasi lebih tinggi, yang hal ini akan berdampak pada perbaikan kondisi perekonomian negara.

MekanismePajak, Sebuah sistem pajak yang berbeda dalam kerangka pemerintahan menekankan padaprinsip dan pengaturan pasar modal untuk para investornya. Di negara-negara yang mengoperasikan sistem pajak klasik, perusahaan dikenakan pajak secara terpisah dari pemegang saham mereka. Perusahaan membayar tingkat diferensial pajak perusahaan pada keuntungan mereka dan pemegang saham membayar pendapatan pajak atas penghasilan dividen yang diterima (Black, 1976). N amun, di negara-negara yang mengoperasikan sistem pajak imputasi parsial, pajak perusahaan dibebankan pada keuntungan perusahaan tetapi bagian dari pajak perusahaan yang dibayar diperhitungkan ketika menilai kewajiban pemegang saham untuk pajak penghasilan (Short et al., 2002).

Orientasi investasi, Di negara maju, umumnya investor melakukan investasi untuk tujuan jangka panjang (dividen), hal ini tampak sebal iknya pada negara berkembang yang melakukan investasi untuk tujuan jangka pendek (capital gain dari penjualan saham). Sehingga sangat penting bagi perusahaan untuk meningkatkan tata kelola perusahaannya, karena akan berdampak pada kinerja keuangannya, baik dicerminkan dari kemampuan dalam membayar dividen maupun dari kenaikan harga sahamnya. Peran manajer di perusahaan sangat penting dalam mengarahkan orientasi investasi tersebut, karena tidak menutup kemungkinan di N egara berkembang dengan kondisi perekonomian yang stabil maka bisa lebih ditekankan pada pemilihan orientasi jangka panjang.

Preferensi Resiko,Denis dan Osobov (2007) menjelaskan bahwa perusahaan yang berusaha untuk meminimalisir resiko melalui kompensasi CEO dapat memotivasi manajer untuk membayar dividen yang lebih besar kepada para investor. Dengan demikian, sangat dibutuhkan tata kelola yang baik untuk mengatasi berbagai resiko perusahaan, baik resiko bisnis maupun resiko investasinya. Baik manajer maupun direksi telah menetapkan secara implisit tentang preferensi resiko yang diterapkan dalam perusahaan.

A kses pendanaan eksternal, Pada negara dengan akses pendanaan eksternal yang mudah dan biaya pendanaan eksternal (biaya utang) yang rendah, peningkatan corporate governance akan meningkatkan dividend payout. Rozeff (1982) menjelaskan bahwa pembayaran dividen meningkatkan biaya pendanaan eksternal, tetapi mengurangi biaya oportunisme manajerial. Sebagai akibatnya, ada payoutoptimal yang meminimalkan jumlah dari biaya dan masalah agensi. Easterbrook (1984) menunjukkan bahwa dividen yang lebih tinggi juga memaksa perusahaan untuk mencari pendanaan eksternal, sehingga manajer melakukan pengawasan yang intensif dari pasar modal primer.

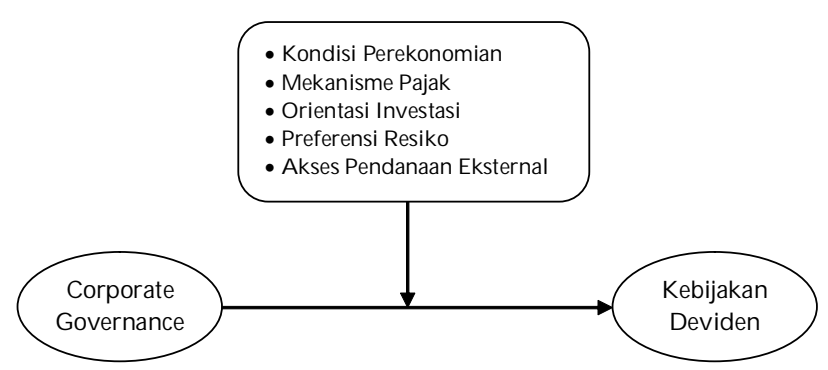

Gambar 1. Model Proposisi Dampak Corporate Governance Atas Kebijakan Deviden 


\section{Dampak Corporate Governance terhadap Keputusan Dividen}

Nur H idayati \& H adi Sunaryo

Gambar 1 diatas merupakan bentuk model proposisi dampak tatakelola perusahaan atas kebijakan deviden yang dapat digeneralisir berdasarkan teori dan temuan penelitian terdahulu.

\section{KESIMPULAN DAN SARAN}

\section{Kesimpulan}

Kajian literatur dalam penelitian ini dapat memberi kesimpulan berupa generalisasi umum bahwasanya:

Tata kelola perusahaan berdampak penting terhadap kebijakan deviden suatu perusahaan, baik dalam konteks negara di Asia, Australia, maupun A frika. Sesungguhnya tata kelola perusahaan bisa berdampak positif maupun negatif terhadap kebijakan deviden suatu perusahaan. $\mathrm{H}$ al ini tergantung kepada stuktur kepemilikan, pola hubungan diantara manajer dan direksi, serta tujuan utama perusahaan - apakah memaksimalkan profit atau memaksimalkan nilai pemegang saham. Tetapi kecenderungan praktek di lapangan menunjukkan dampak negatif, hal ini dkarenakan banyak faktor yang disinyal ir mampu memoderasi dampak (baik positif maupun negatif) dari tata kelola terhadap kebijakan deviden tersebut. Dengan demikian, dampak corporate governance terhadap kebijakan dividen pada negara berkembang dan negara maju sekiranya dapat dimoderasi oleh beberapa hal eksternal yang tersirat antara lain: 1) Kondisi Perekonomian, 2) MekanismePajak, 3) Orientasi investasi, 4) Preferensi Resiko, dan 5) A kses pendanaan eksternal.

\section{Saran}

Peneliti menyarankan adanya penelitian di masa mendatang yang tidak hanya menganalisis atau mengkaji dampak corporate governance terhadap kebijakan dividen di beberapa negara A sia, Australia, dan Afrika, tetapi juga di beberapa negara di Amerika dan Eropa. Perlunya pengem- bangan konstruk tata kelola perusahaan yang lebih komprehensif, dengan meliputi berbagai proksi terkait konsep tersebut, tetapi hal ini bisa jadi berbeda untuk metode pelaporan lewat indeks tata kelola yang telah dipublikasikan oleh lembaga yang berwenang. Selain itu perlunya menguji pengaruh moderasi dari kondisi perekonomian, mekanisme pajak, orientasi invesatasi, preferensi resiko dan atau akses pendanaan eksternal. Sehingga hasil komparasi yang bersifat komprehensif dapat memberikan informasi serta celah baru atas implikasi praktis dan teoritis yang memungkinkan untuk muncul. Selain itu, perlu juga mempertimbangkan hal lain yang dapat mempengaruhi kebijakan dividen, seperti tingkat inflasi, suku bunga, sehingga memberikan tambahan informasi yang lebih luas untuk kajian corporate governance.

\section{DAFTAR PUSTAKA}

Adjaoud, F. and Ben-Amar, W. 2010. Corporate Governance and Dividend Policy: Shareholders Protection or Expropriation?.Journal of Business Finance \& A ccounting, Vol. 37 Nos 5/ 6,pp. 648-667.

Ang, J.S., Fatemi, A. and Tourani-Rad, A. 1997. Capital Structure and Dividend Policies of Indonesian Firms.Pacific-Basin Financelournal, Vol. 5 No. 1, pp. 87-103.

Baker, H.K. and Powell, G.E. 2012. Dividend Policy in Indonesia: Survey Evidence from Executives. Journal of A sia Business Studies, Vol. 6 No. 1, pp. 79-92.

Bellamy, D. 1994. Evidence of Imputation Clienteles in the Australian Equity Market.A siaPacific Journal of $\mathrm{M}$ anagement, Vol. 11 No. 2, pp. 275-287.

Brigham, Eugene E., Louis C. Gapenski, dan Philip R. Daves. 1999. Intermediate Financial M anagement. Sixth Edition. Orlando: The Dryden Press.

Caliskan, Deren and John, A. Doukas. 2015. CEO Risk Preferences and Dividend Policy Decisions. M anuscript. Old Dominion University, USA.

Claessens, S. and Djankov, S. 1999. Ownership Concentration and Corporate Performance in theCzech Republic.Journal of Comparative Economics, Vol. 27, pp. 498-513. 


\section{Jurnal Keuangan dan Perbankan | KEUANGAN}

Vol. 20, N o.1, Januari 2016: 32-41

Da Silva, C.L., Goergen, M. and Renneboog, L. 2004.D ividend Policy and Corporate Governance. Oxford: Oxford University Press.

Denis, David J. dan Igor Osobov. 2007. Why do Firms Pay Dividends ? International Evidence onthe D eterminants of Dividend Policy. A vailable on-line at www.ssrn.com.

Easterbrook, F. 1984. Two Agency-Cost Explanation of Dividends.American Economic Review,Vol. 74, pp. 650-659.

Faccio, M., Lang, L. and Young, L. 2001. Dividends and expropriation.A merican EconomicReview, Vol. 91, pp. 54-78.

Fama, E.F. and Jensen, M.C. 1983. Separation of Ownership and Control.Journal of Law\& Economics, Vol. 26, pp. 301-325.

Fama, E. and French, K. 2002. Testing Tradeoff and Pecking Order Predictions About Dividends and Debt.Review of Financial Studies, Vol. 15, pp. 1-33.

Farinha, J. 2003. Divided Policy, Corporate Governance and the Managerial Entrenchment Hypothesis: An Empirical Analysis.Journal of Business Finance \& A ccounting, Vol. 30,pp. 1173-209.

Farida, Y.N., Prasetyo, Y., dan Herwiyanti, E. 2010. Pengaruh Penerapan Corporate Governance Terhadap TimbulnyaEarning Management dalam Menilai Kinerja Keuangan pada Perusahaan Perbankan di Indonesia. Jurnal Bisnis dan A kuntansi, Vol 12, No 2, pp. 69-80.

Francis, B.B., Hasan, I., John, K. and Song, L. 2011. Corporate Governance and Dividend Payout Policy: A Test Using Antitakeover Legislation. Financial $\mathrm{M}$ anagement, $\mathrm{Vol} .40 \mathrm{~N}$ o. 1,pp. 83-112.

Fenn, G.W. and Liang, N ..2001. Corporate Payout Policy and Managerial Stock Incentives. Journal of Financial Economics, Vol. 60, pp. 45-72.

Gugler, K. 2003. Corporate Governance, Dividend PayoutPolicy, and thelnterrelation between Dividend, $R \& D$, and Capital Investment.journal of Banking and Finance, Vol. 27 pp. 1297-1321.

Harada Kimie and Pascal N guyen. 2011. Ownership Concentration and Dividend Policy in Japan.M anagerial Finance, Vol. 37 Iss 4 pp. 362 379.
Henry, D. 2011. Ownership Structure and Tax-Friendly Dividends.J ournal of Banking \& Finance, $\mathrm{Vol} .35 \mathrm{No}$. 10, pp. 2747-2760.

Jensen, M. C., dan Meckling, W.H. 1976. Theory of the Firm: Managerial Behavior, Agency, and Ownership Structure. Journal of Financial Economics, pp. 305-360.

Jensen, M.C. 1993. The Modern Industrial Revolution, Exit and the Failure of Internal Control Systems.Journal of Finance, Vol. 48, pp. 831-880.

Jensen, M. 1986. Agency Costs of Free Cash Flow, Corporate Finance and Takeovers. A mericanE conomic Review, Vol. 76, pp. 323-9.

Jiraporn, P. and Ning, Y. 2006. Dividend Policy, Shareholder Rights, And Corporate Governance Journal of A pplied Finance, Vol. 16 No. 2, pp. 24-36.

John, K. and Senbet, L.W. 1998. Corporate Governance and Board Effectiveness.Journal ofBanking \& Finance, Vol. 22, pp. 371-403.

Joshua Abor Vera Fiador. 2013. Does Corporate Governance Explain Dividend Policy in Sub-Saharan Africa?.International Journal of Law and $M$ anagement, Vol. 55 Iss 3 pp. 201 - 225.

Jun, A., Gallagher, D.R. and Partington, G.H. 2011. Institutional Dividend Clienteles Under an Imputation Tax System.Journal of Business Finance \& A ccounting, Vol. 38 Nos 1-2,pp. 198-224.

Kanagaretnam, K., Lobo, G.J., dan Whallen, D.J. 2007. Does good Corporate Governance Reduce Information Asymmetry A round Quarterly Earnings Announcements?. Journal of Accounting \& Public Policy, Vol. 26, PP 497-552.

Knyazeva, A. 2007. Delivering on the Dividend Promise: Corporate Governance, Managerial Incentives and Dynamic Dividend Behavior.Job M arket Paper, New York University, NY.

Kowalewski, O., Stetsyuk, I. and Talavera, O. 2008. Does Corporate Governance Determine Dividend Payouts in Poland?.Post-Communist E conomies, $\mathrm{Vol}$. 20 No. 2, pp. 203-218.

Kyereboah-Coleman, A. and Amidu, M. 2008. The Link Between Small Business Governance and Performance: The Case of The Ghanaian SME Sector.Journal of African Business, Vol. 9No. 1, pp. 120-143. 


\section{Dampak Corporate Governance terhadap Keputusan Dividen}

Nur H idayati \& H adi Sunaryo

La Porta, R., Lopez-de-Silanes, F., Shleifer, A . and Vishny, R.W. 2000. Investor Protection and Corporate.J ournal of Financial Economics, Vol.58Nos 1/ 2, pp. 3-27.

Leal, R.P. and Carvarhal-dal-silva, A.L. 2007. Corporate Governance and Value in Brasil (and Chile)", in Chong, A. and Lopez-des-Silanes, F. (Eds), Investor Protection and Corporate Governance: Firmlevel Evidence Across Latin A merica.The Inter A merican D evelopment Bank, Washington, DC, pp. 213-287.

Mahadwartha, P.A. 2003. Predictability Power of Dividend Policy and Leverage Policy to Managerial Policy in Indonesia: an Agency Theory Perspective. Jurnal Ekonomi dan Bisnis Indonesia, Vol. 18 No. 3, pp. 288-297.

Mitton, T. 2004. Corporate Governance and Dividend Policy in Emerging Markets.Emerging $M$ arkets $\mathrm{Re}$ view, Vol. 5 No. 4, pp. 409-426.

Pattenden, K. and Twite, G. 2008. Taxes and Dividend Policy Under Alternative Tax Regimes. Journal of Corporate Finance, Vol. 14 No. 1, pp. 1-16.

Rozeff, S.M. 1982. Growth, Beta and Agency Cost as De terminants of Dividend Payout Ratios. Journal of Financial Research, Vol. 5, pp. 411-433.

Setiawan, Doddy and Lian, K. Phua. 2013. Corporate Governance and Dividend Policy in Indonesia.Business Strategy Series, Vol. 14 Iss 5/ 6 pp. $135-143$.
Shleifer, A. and Vishny, R.W. 1986. Large Shareholders and Corporate Control.Journal of Political Economy, Vol. 94, pp. 461-488.

Shleifer, A. and Vishny, R. 1997. A Survey of Corporate Governance.Journal of Finance,Vol. 52, pp. 737-83.

Tabalujan, B.S. 2001. Corporate Governance of Indonesian Banks: the Legal and Business Contexts.A ustralian Journal of Corporate Law, Vol. 13, pp. 67.

Tobias, Basse and Sebastian, Reddemann. 2011. Inflation and the Dividend Policy of US Firms. $M$ anagerial Finance, Vol. 37 Iss 1 pp. 34 - 46.

Yermack, D. 1996. Higher Market Valuation of Companies with a Small Board of Directors. Journal of Financial Economics, Vol. 40 No. 2, pp. 185-211.

Yarram,S. Reddy. 2015. Corporate Governance Ratings and the Dividend Payout Decisions of Australian CorporateFirms. International Journal of M anagerial Finance, Vol. 11 Iss 2 pp. 162 - 178.

Zhang, Haiyan. 2005. Corporate Governance and Dividend Policy: a Comparison of ChineseFirms Listed in Hong Kong and in the Cina daratan. Tesis (Tidak di Publikasikan). The Hong Kong University of Science and Technology. 